\title{
Increased Expression of Matrix Metalloproteinase-9 in Patients with Temporal Lobe Epilepsy
}

\author{
Temporal Lob Epilepsisi olan Hastalarda Artmuş Matriks \\ Metalloproteina:-9 Ekspresyonu
}

Goksemin ACAR ${ }^{1}$, Gamze TANRIOVER², Feridun ACAR², Ramazan DEMIR ${ }^{2}$

${ }_{1}^{1}$ Pamukkale University, School of Medicine, Department of Neurology, Denizli, Turkey

2 Akdeniz University, School of Medicine, Department of Histology and Embryology, Antalya, Turkey

${ }^{3}$ Pamukkale University, School of Medicine, Department of Neurosurgery, Denizli, Turkey

Corresponding Author: Goksemin ACAR / E-mail: goksemind@yahoo.com

\begin{abstract}
AIM:The molecular mechanism of epileptogenesis in temporal lobe epilepsy is still unclear. Experimental studies have suggested that matrix metalloproteinases have important roles in this process, but human studies are limited. The aim of this study was to assess the expression of MMP-9, MMP-2 and their tissue inhibitors (TIMP-1 and TIMP-2) in patients with temporal lobe epilepsy with hippocampal sclerosis (TLE-HS).

MATERIAL and METHODS: The tissue samples from temporal neocortex and hippocampus were obtained from patients with temporal lobe epilepsy with hippocampal sclerosis who had undergone anterior temporal lobectomy for recurrent medically resistant seizures. Immunohistochemical methods were used to determine the expression of MMP-9, MMP-2 and their tissue inhibitors. Tissue samples were also analyzed with transmission electron microscopy.

RESULTS: The immunoreactivity for MMP-9 both in hippocampal and temporal neocortical neurons was stronger than that of MMP-2. Additionally, there was a mild reaction for its tissue inhibitor TIMP-1 as with TIMP-2. The TEM analysis of the hippocampus revealed that there was apparent ultra-structural damage on the pericarya and neuropil of some neurons. There was obvious damage in the mitochondria and the nuclear membrane.
\end{abstract}

CONCLUSION: The preliminary results of this study revealed that MMP-9 may have a role in patients with drug resistant TLE-HS.

KEYWORDS: Hippocampal sclerosis, Matrix metalloproteinase-9, Temporal lobe epilepsy

Öz

AMAÇ: Temporal lob epilepsisinde moleküler epileptogenez mekanizmalar halen tam anlaşılamamıştır. Deneysel çalışmalar matriks metaloproteinazların bu süreçte önemli rolü olduğunu ileri sürmektedir, ancak bu konuda insan çalışmaları kısıtıdır. Çalışmanın amacı, hipokampal sklerozun eşlik ettiği temporal lob epilepsisi (TLE-HS) olan hastalarda MMP-9, MMP-2, TIMP-1 ve TIMP-2 ekspresyonunu değerlendirmektir.

YÖNTEM ve GEREÇLER: Illaca dirençli epilepsi nedeniyle anterior temporal lobektomi yapılan TLE-HS hastalarından alınan hipokampus ve temporal neokorteks dokuları kullanıldı. MMP-9, MMP-2, TIMP-1 ve TIMP-2 ekspresyonunu incelemek için immünohistokimyasal yöntemler kullanıldı ve dokular transmisyon elektron mikroskopisiyle incelendi.

BULGULAR: MMP-9 immünoreaktivitesi hem hipokampal hem de neokortikal nöronlarda MMP-2'ye göre daha güçlü bulundu. Doku inhibitörüü olan TIMP-1'in de ılımlı bir immünoreaktivite gösterdiği tespit edildi. TEM analizinde hipokampal nöronlarda özellikle mitokondriyal ve nükleer membranın belirgin derecede hasara uğradığı tespit edildi.

SONUÇ: Çalışma, MMP-9'un TLE-HS'da rol oynayabileceğini düşündürmektedir.

ANAHTAR SÖZCÜKLER: Hipokampal skleroz, Matriks metalloproteinaz-9, Temporal lob epilepsi

\section{INTRODUCTION}

Temporal lobe epilepsies (TLEs) comprise a heterogeneous group of disorders sharing the same topographical seizure onset. TLE with hippocampal sclerosis is the most common type of epilepsy in adults. In one third of the patients seizures cannot be controlled by pharmacological therapies and may require further surgical approaches. Therefore, it is necessary to understand the molecular mechanisms of this devastating disease.
Neuronal degeneration is one of the hallmarks of mesial TLE (MTLE). A preferential neuron loss is characteristic in the CA1, CA 3 and the hilus regions of the hippocampus. Besides, extra-hippocampal neuron loss has also been observed in MTLE in the entorhinal cortex, pyriform cortex and amygdala. However, it is not clear whether neuronal loss is the cause or the consequence of repetitive seizures $(4,11)$. Another important finding in MTLE with hippocampal sclerosis (MTLEHS) is chronic astroglial activation which results in sclerosis by increasing inflammatory cytokine production and thus 
potentiating excessive synaptic activity and inducing a "travelling effect" as activated astrocytes migrate to the epileptic focus $(2,13,27)$. During epileptogenesis, aberrant synaptic plasticity and mossy fiber sprouting have been assumed as the main reason of epileptic focus formation. Mossy fiber sprouting is characterized by dentate granule cell axons forming synapses with cells in the granular layer and inner molecular layer rather than in the CA3 region of the hippocampus (33). Although the environmental changes deriving from seizures that drive sprouting are yet unclear, gliosis, release of cytokines, growth factors and adhesion molecules from activated astrocytes and microglia may have crucial role (42). According to Pitkanen and Sutula, sprouting is progressive and is brought on by recurrent seizures (29). The recurrent excitation hypothesis is supported by the fact that mossy fibers are glutamatergic axons and by evidence of excitatory circuit formation within the inner molecular layer (33). On the contrary, it is believed that mossy fiber sprouting serves to reform inhibitory circuits that are lost during the initial damage to neurons where mossy fibers synapse primarily on inhibitory inter-neurons (11). Besides, it has been noted that mossy fiber sprouting occurs secondary to neuron loss (15).

Recently, matrix metalloproteinases' (MMPs) are found to be a possible key factor in epilepsy. MMPs are a large family of zinc dependent proteinases that are considered major elements conducting the extracellular matrix (ECM) remodeling and have pivotal role in cancer invasion and metastasis $(1,34)$. Many studies have identified that MMPs are associated with various central nervous system (CNS) pathologies including stroke, traumatic brain injury, cerebral arteriovenous malformation, influenza associated encephalopathy and in bacterial meningitis where it has been identified as a risk factor for developing neurological sequel $(8,22,39)$. Moreover, many studies have reported that MMP-9 has implication in synaptic plasticity, learning and memory $(21,25,28,36)$. Also, MMP2 has been implicated in dendritic remodeling (36), axonal sprouting (30), synaptic plasticity, and learning in the hippocampus $(5,21)$.

The activity of MMPs is counterbalanced by their natural inhibitors, the tissue inhibitors of matrix metalloproteinase's (TIMPs). In recent studies a physiological role of MMP-9 and its tissue inhibitor, TIMP-1, has been postulated in neuronal plasticity as well as long term potentiation $(16,24)$. Recently, Wilczysky and colleagues have reported MMP-9 is an essential molecule in pentylenetetrazole epileptogenesis and MMP9 deficiency diminished aberrant synaptogenesis (41). In relation to epilepsy it is suggested that MMP-9 cleaves ECM molecules in and around the synaptic cleft where this is thought to be a necessary step in the cascade of events leading to new synapse formation.

The studies mentioned above are all experimental and the role of MMPs in human epilepsy is still obscure. Therefore, the aim of this study was to determine the hippocampal and neocortical expressions of MMP-9 and MMP-2 and their natural tissue inhibitors TIMP-1 and TIMP-2 in human MTLEHS by using immunohistochemical methods. Here, we report the preliminary results of this study.

\section{MATERIAL and METHODS}

\section{Patient Selection}

Patients with mesial temporal lobe epilepsy associated with hippocampal sclerosis were enrolled in this study. Tissue samples of hippocampus and temporal neocortex were obtained from 3 ( 1 female, 2 male) patients with temporal lobe epilepsy with hippocampal sclerosis who had anterior temporal lobectomy surgery for recurrent medically resistant epileptic seizures. Informed consent for the use of tissue in research was obtained before surgery.

All of the patients' presurgical evaluations were consisted of detailed history and neurological examination, interictal and ictal electroencephalogram (EEG), neuropsychological testing and neuroimaging studies. All of the patients were refractory to multiple trials of antiepileptic drugs. Neuroimaging studies also revealed that none of them had a progressive disease in CNS. After surgical removal of the anterior temporal lobe, hippocampus and amygdala, conventional neuropathologic examination revealed mesial temporal sclerosis.

\section{Tissue Processing}

Adequate amount of the resected materials were immediately fixed in $10 \%$ buffered in formalin for $24 \mathrm{~h}$. Formalin-fixed tissue samples were embedded in paraffin and cut into $5 \mu \mathrm{m}$ sections. $5 \mu \mathrm{m}$ thick serial sections were collected on poly-Llysine coated slides (Sigma-Aldrich, St. Louis, MO, USA) and incubated overnight at $56^{\circ} \mathrm{C}$.

Adequate amount of tissue samples were fixed with phosphate buffered ( $\mathrm{pH} 7.4$ ) $2.5 \%$ glutaraldehyde solution for trensmision electron microscopy.

\section{Immunohistochemistry}

For MMP-9, MMP-2, TIMP-1 and TIMP-2 immunohistochemistry, paraffin sections were deparaffinized and blocked for endogenous peroxidase activity with methanol containing $3 \%$ $\mathrm{H}_{2} \mathrm{O}_{2}$ for 15 min. and for nonspecific binding with universal blocking reagent (BioGenex, San Ramon, CA, USA) for 10 min. at room temperature (37). Anti-rabbit MMP-9 (Neomarkers cat\#RB-1539P), MMP-2 (Neomarkers cat\#RB-1588P), TIMP1 (Neomarkers cat\# RB-1531P), TIMP-2 (Neomarkers cat\# RB-1489P) and anti-rabbit cleaved caspase-3 (Asp 175) (Cell Signaling \#9661) antibody diluted in dilution buffer (1/5000, $1 / 400,1 / 200,1 / 400,1 / 250$, respectively) were applied for overnight at $+4{ }^{\circ} \mathrm{C}$ in a humidified chamber. For negative controls the primary antibodies were replaced by normal rabbit IgG serum (Vector Lab. Burlingame, CA, USA) at the same concentration. After several washes in PBS, sections were incubated with biotinylated goat anti-rabbit lgG secondary antibody (1/400 dilution Vector Lab. Burlingame, CA, USA) for $1 \mathrm{~h}$. followed by LSAB streptavidin-peroxidase complex (Dako, Carpinteria, CA, USA) incubation for $45 \mathrm{~min}$. and were rinsed 
with PBS. Antibody complexes were visualized by incubation with diaminobenzidine (DAB) chromogen (BioGenex). Sections were counterstained with Mayer's hematoxylin (Dako), dehydrated, mounted and examined by a Zeiss-Axioplan (Oberkochen, Germany) microscope.

\section{Transmission Electron Microscopy (TEM) Analysis}

Tissue samples were fixed with phosphate buffered ( $\mathrm{pH}$ 7.4) $2.5 \%$ glutaraldehyde solution followed by 1 hour at $4^{\circ} \mathrm{C}$ with $2 \%$ osmium tetroxide. Samples were dehydrated through a gradually increasing series of ethanol and embedded in Araldite resin (Araldite CY 212, $91 \mathrm{ml}+$ dodecenyl succinic anhydride (DDSA) $84 \mathrm{ml}+\mathrm{N}, \mathrm{N}$-dimethylbenzylamine (BDMA) $3.5 \mathrm{ml}$, TAAB Company, England). Semi-thin $(1 \mu \mathrm{m})$ and thin $(40-60 \mathrm{~nm}$.) sections were cut using diamond knives on a Leica ultramicrotome (Leica ultracut, UCT, Leica MZ6, England). Ultra-thin sections were collected on copper grids. In thin sections, double-contrast staining was applied with uranyl acetate (100 $\mathrm{ml}$ methanol and $5 \mathrm{~g}$ uranyl acetate) and Reynold's lead nitrate solution (1.76 g sodium citrate, $1.33 \mathrm{~g}$ lead nitrate, $50 \mathrm{ml}$ distilled water and $8 \mathrm{ml} 1 \mathrm{~N} . \mathrm{NaOH}$ ). Thin sections were examined using a LEO 906 transmission electron microscope (Leo 906E, Zeiss, Germany).

\section{RESULTS}

\section{MMP-9}

Despite the cytoarchitectural damage, the neuronal expression of MMP-9 was more significant than MMP-2, particularly on mossy fibers. Both neurons and glial cells were labeled by the MMP-9 in CA1 and CA2 hippocampal subfields. Likewise, strong immunoreactivity for MMP-9 was seen in the granular cell layer of the dentate gyrus (Figure 1A, MMP-9). In the temporal neocortex the cytoplasmic immunoreactivity for MMP-9 was so strong enabling to visualise the dendritic and axonal projections (Figures 1E, F).

\section{MMP-2}

The neurons in the CA1 (Figure 1B, MMP-2) and CA2 (Figure 1C, MMP-2) regions showed strong cytoplasmic immunoreactivity for MMP-2, however there was mild immunoreaction in CA3 neurons due to the damaged cytoarchitecture (Figure 1D, MMP-2). In the neocortex, pyramidal neurons showed strong cytoplasmic immunoreactivity, but the glial cells were not immunostained (Figures 1E, F, MMP-2).

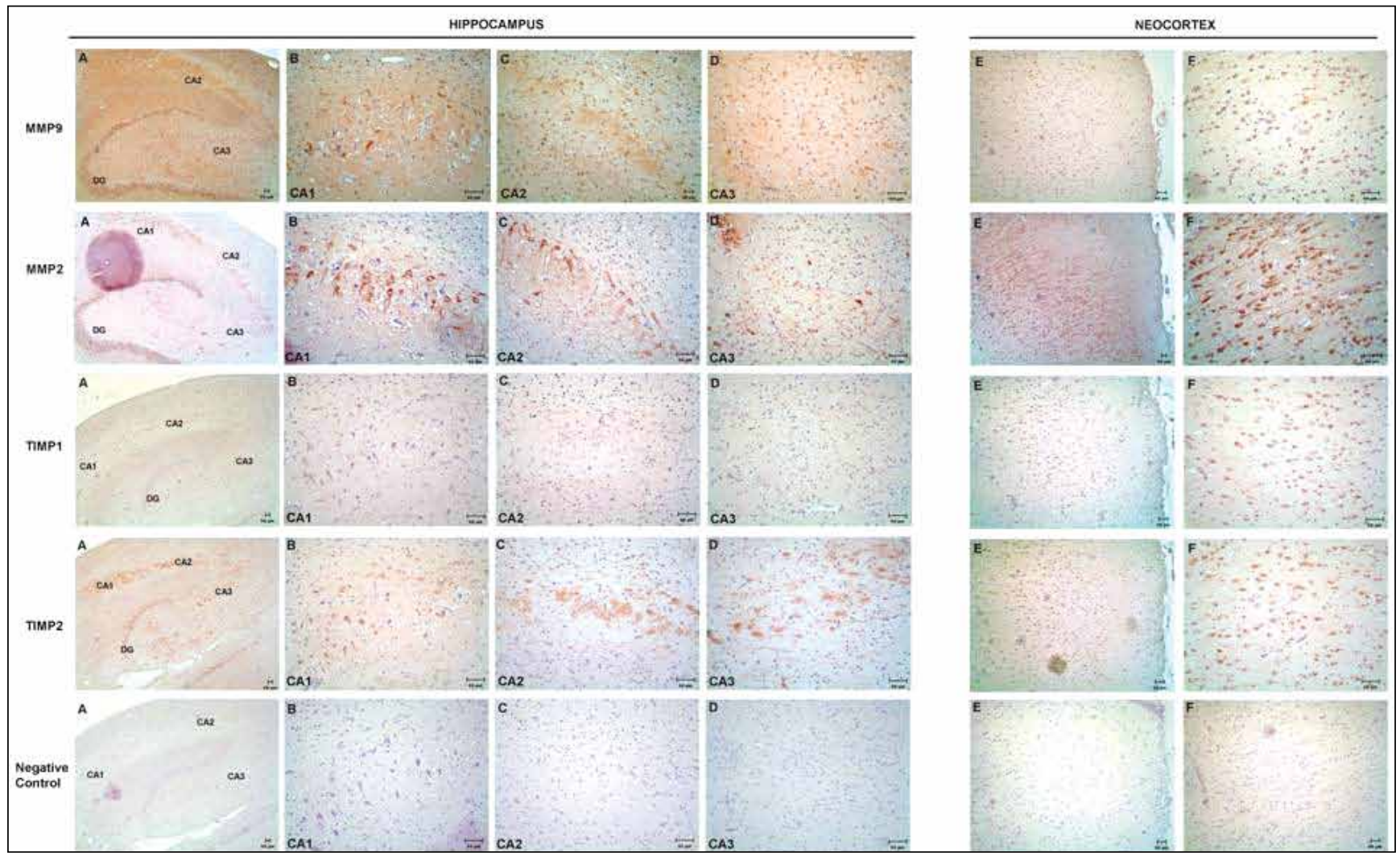

Figure 1: Representative photomicrograph of MMP9/2 and their natural tissue inhibitors TIMP-1/2 stainings in hippocampal subregions and neocortex in human MTLE-HS patients. Localisation of the antibodies were revelaled in hippocampal and cortical fileds by line. MMP9 and -2 were found to be expressed in all hippocampal subfields. MMP9 and -2, on the other hand, were expressed at higher levels in DG, CA1 and CA2 subregion in comparison with the CA3 hippocampal subfield. A pronounced expression of TIMP-1/2 was notable in all CA1 subregions. The neocortical TIMP-1 expression was very similar to TIMP-2 expression. Negative-control section. Please note the absence of MMP9/2 and TIMP-1/2 immunostainings in hippocampal subregions and neocortex. Scale bars represent $50 \mu \mathrm{m}$. 


\section{TIMP-1}

The CA1 neurons exhibited a weak immunoreactivity with TIMP-1 (Figures 1A,B TIMP-1). Moreover, the reaction was also weak in the mossy fibers in CA1 and CA2 subregions (Figures $1 \mathrm{~B}, \mathrm{C}$; TIMP-1) while no immunoreaction was detected in the CA3 subregion of human hippocampus (Figure 1D; TIMP-1). However, the immunoreactivity was weak in the pyramidal neurons in the granular cell layer of the dentate gyrus (Figure $1 \mathrm{~A}$; TIMP-1). The neocortical reactivity for TIMP-1 in neurons was strong in parallel with MMP-9 (Figures 1E, F; TIMP-1).

\section{TIMP-2}

There was a moderate cytoplasmic TIMP-2 immunolabelling localized in the CA1 hippocampal subregion neurons (Figure 1B; TIMP-2), and a strong mossy fibers immunolabelling were also observed in CA2 and CA3 hippocampal subregions (Figures 1 C, D; TIMP-2). The neocortical TIMP-2 expressions were very similar to TIMP-1 expression (Figures 1E, F; TIMP-2).

Negative control immunostaining with normal rabbit IgG confirmed the specificity of MMP9/2 and TIMP-1/2 staining patterns in hippocampal subregions and neocortex (Figures 1 A- F; Negative control panel).

\section{Caspase-3}

The antibody specific for activated caspase-3 selectively labeled the cytoplasm of cells that had a morphology consistent with apoptosis. Occasional nuclear staining was observed in neocortex. In CA subregions of the hippocampus, activated caspase-3-labelled cells were clearly detected (Figures $2 \mathrm{~A}-\mathrm{C}$ ).

\section{TEM Analysis}

The TEM analysis of the hippocampus revealed that there was apparent ultra-structural damage on the pericarya and neuropil of some neurons. (Figures 3A, B). There was an obvious damage in the mitochondria and the nuclear membrane was ondulated and fragmented in hippocampal neurons. Especially in some hippocampal neurons pericarya was invaded by dense structure in cytoplasm (Figure 3B).

By TEM, some of the sub-cellular components and synaptic connections of the neocortex showed a normal structural organization. But, some of the pyramidal neurons were clearly observed with euchromatic nucleus, including very active nucleoli and subcellular organelles (Figures 3C,D). The necrotic pericarya were observed with an irregular shape and dense cytoplasm containing many vacuoles, and a definitive pycnotic nucleus with nucleoli. There was an obvious mitochondrial damage such as cristae degeneration and matrix loss in the cytoplasm of both hippocampal and neocortical neurons (Figures 3A-D). Moreover, in some areas there was a considerable number of normal appearing myelin sheaths with axoplasm (Figure 3D). Moreover, TEM analysis compatible with the caspase-3 immunostaining and also reflected the immune results.

\section{DISCUSSION}

Recent studies have linked MMPs to various CNS disorders including multiple sclerosis, Alzheimer's disease, malignant glioma, Parkinson's disease (24). Also in epilepsy it is demonstrated that kindling progression persistently increased MMP-9 protein expression and activity in the mouse hippocampus, whereas acute convulsions had little effect on
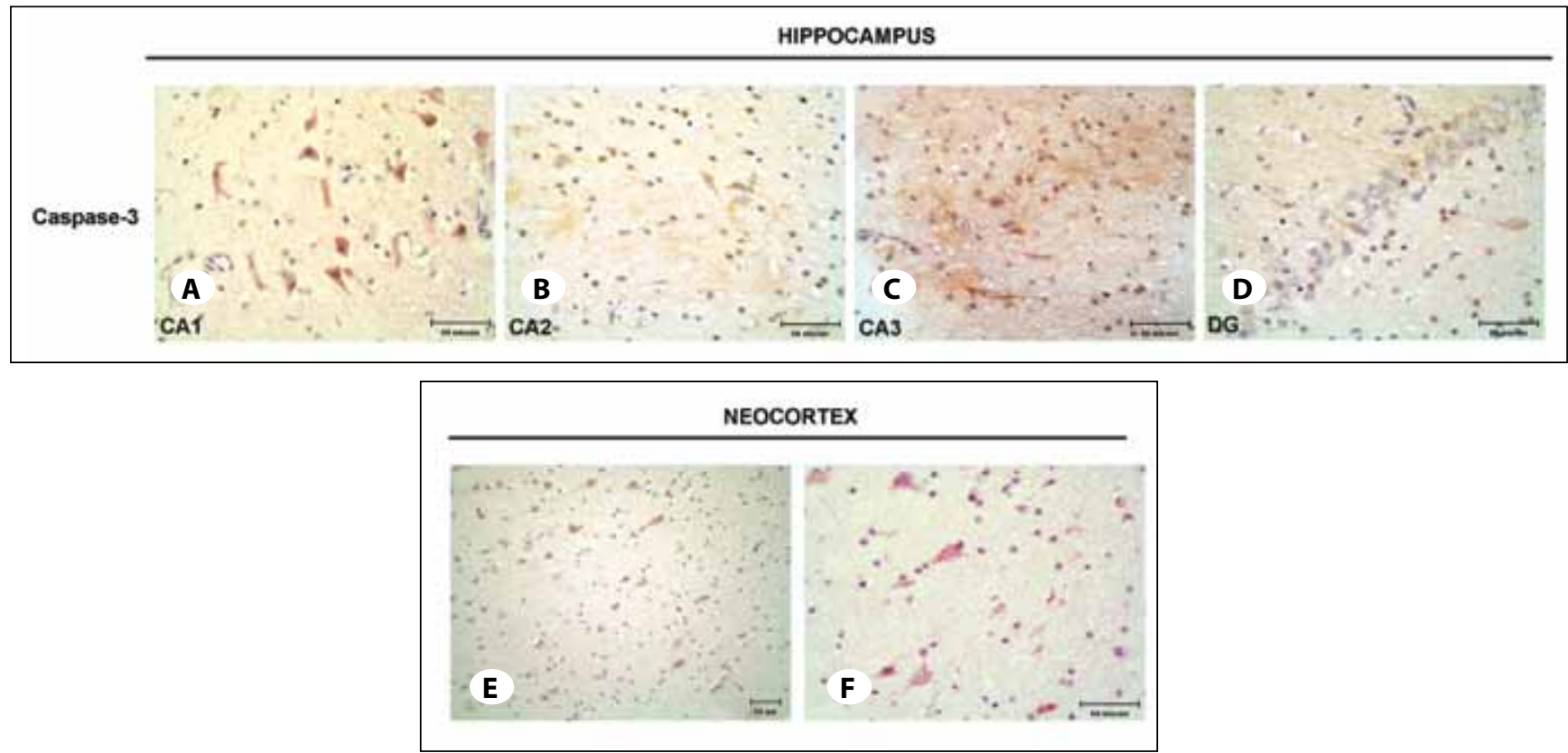

Figure 2: Localization of Caspase-3 protein in human hippocampal subregions and neocortex in MTLE patients. Caspase-3 immunoreactvity was clearly observed in CA1 (A), CA2 (B) and CA3 (C) subregions. There was weakly immunolabelled with Caspase-3 in dentate gyrus (D). Scale bars represent $50 \mu \mathrm{m}$. 
MMP-9 (23). In parallel with this, previous studies revealed that MMP-9 mRNA levels increased in response to neuronal depolarization in the rat hippocampus (32). Konopacki et al. also demonstrated that MMP-9 mRNA is transported to dendrites and synapses in the hippocampal dentate gyrus after seizure in kainic acid treated rats (19).

There are convincing preclinical studies demonstrating that the expression and activity of MMP-9 is regulated by repetitive activation of NMDA receptors (23). In fact, the inhibition of NMDA receptors prevented PTZ-induced convulsions and kindling (9). Besides, excessive levels of synaptic glutamate and persistent influx of $\mathrm{Ca}^{+2}$ through NMDA receptors are considered as major causes of epileptogenesis (7). It has been reported that the expression and activity of MMP-9 depend on NMDA receptor activation and are associated with LTP development $(21,25)$. Moreover, activation of NMDA receptors leads to MMP mediated modification of cell adhesion molecules and the development of dendritic spines (38). Dendritic spine morphology and synaptic potentiation are dynamically modulated by ECM proteins and cell surface proteins with which they interact. It is suggested that ECM remodelling has an important role in synaptic plasticity.
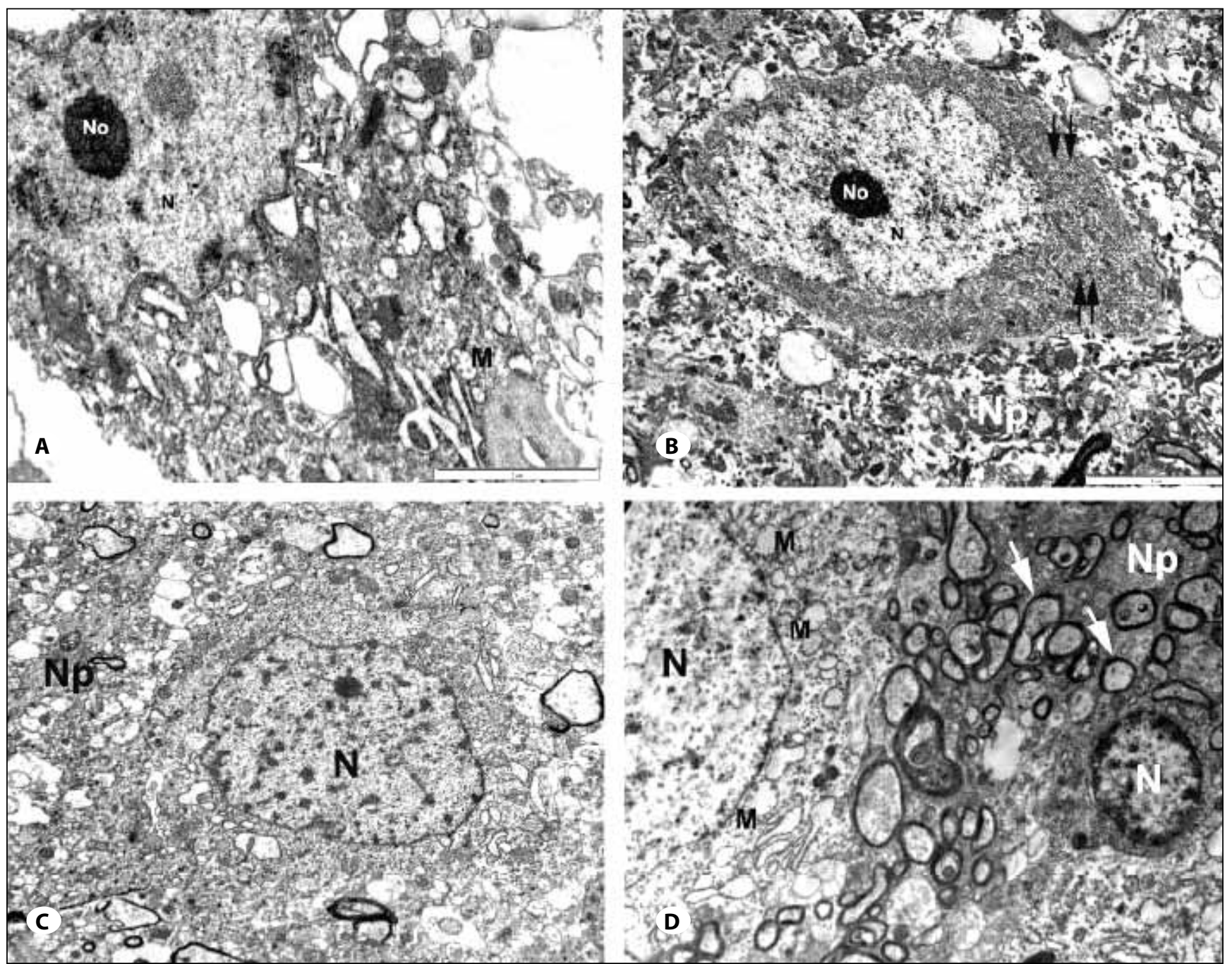

Figure 3: The ultrastructure of hippocampus (A, B) and neocortex (C, D) with some cellular components are seen in MTLE patients. Nucleus with definitive nucleoli and with ondulated membrane of a pericaryon was shown structural damage (A). Generally, pericaryon and neuropil (Np) with subcellular elements were not seen in normal appearance (A-D). These pericaryons have an euchromatic nuclei (N) with definitive nucleoli (No). Some pericaryon of hippocampal tissue were observed different structural condition; such as more accumulation of dense granules and organells in cytoplasm (double arrows). The pericaryons of cortical tissues were in normal condition with definitive nuclei and nucleoli (No). Neurophilic areas showed some destructional arrangement. But, the myelin sheaths with many regular lamellae and axoplasm were clearly observed in normal condition (D; with arrows). The cytoplasm of the pericaryon with many organells and amount of inclusions and heterochromatic nucleus $(N)$ were seen $(A-D)$ in hippocampus and neocortex. Marked inner membrane forming cristae break down and matrix loss in some mitochondria (A, D). N: Nucleus, No: Nucleolus, A: Axoplasma, Np: Neuropilic area, M: Mitochondria. Scale bars: A, D: $2 \mu \mathrm{m} ; \mathbf{B}, \mathbf{C}: 5 \mu \mathrm{m}$. 
Wilczynsky et al. demonstrated that the sensitivity of PTZ epileptogenesis is decreased in MMP-9 knockout mice but is increased in a transgenic rat line overexpressing MMP-9 (41). In addition to this, electron microscopic studies revealed that MMP-9 is associated with hippocampal dendritic spines bearing excitatory synapses, where both the MMP-9 protein levels and enzymatic activity strongly increased upon seizures. Furthermore in the same study, seizure evoked pruning of dendritic spines and aberrant synaptogenesis were decreased in MMP-9 deficiency. It has also been suggested that cleaving the ECM molecules in and around the synaptic cleft by MMP9 activity may be an essential step in the cascade of events leading to new synapse formation (41).

In parallel to these findings Mizoguchi et al. provided additional data suggesting that mossy fiber sprouting induced by repeated PTZ treatment was reduced in MMP9 null mice compared to wild type mice, suggesting that increased hippocampal MMP-9 activity is associated with sprouting of mossy fibers (23). Besides, the previous studies have also revealed that several MMPs are acutely upregulated after status epilepticus (12). These findings suggest that MMP9 takes part in epileptogenesis both in acute and chronic processes.

The studies assessing the changes in MMP/TIMP ratio and MMP activity have shed some light on the developmental and pathological processes that occur in CNS $(18,31,43)$. In vivo experiments showed that TIMP-1 has implication in neuronal death and axonal sprouting in pathological situations as well as in the synaptic mechanisms underlying learning and memory in physiological conditions. In epilepsy, the upregulation of MMP inhibitors is also demonstrated in several studies. For instance, a broad spectrum MMP inhibitor can prevent kainate-induced neurodegeneration $(6,17)$. The upregulation of the TIMPs may act as a compensatory mechanism to counterbalance the increased expression of MMPs. These data support the idea that the control of proteolysis is instrumental for pathological and physiological processes in the brain (17). Overall these experimental evidences emphasize the role of MMP-9, as a key participant in neural death, aberrant synaptic plasticity and neuroinflammation that directly effects remodeling of synaptic linkage and that could represent a pharmacological target in epilepsy. Although there is cumulative evidence indicating MMP-9 is a key factor in epileptogenesis in experimental models, its role in human epilepsy is still obscure. In a clinical study in children with prolonged febrile seizures and convulsive status epilepticus, it is reported that serum MMP-9 levels and the ratio of MMP-9 to TIMP-1 is elevated when compared to patients with simple partial seizures, West syndrome and controls (35). In a Norwegian cohort designed to identify possible variants of the MMP-9 gene associated with TLE failed to show any polymorphisms in selected single nucleotide polymorphism of the human MMP-9 gene that are associated with TLE, MTLE-HS or TLE with febrile seizures (14).

In human epilepsy it is impossible to know what happens during the early stages of epileptogenesis and the findings of tissue based human epilepsy studies reflect the late stage of the epileptogenetic processes. This study is the first study in the medical literature demonstrating that MMP-9 expression in the hippocampus is increased in human MTLE-HS just as in the case of experimental epilepsy models. The preliminary results of our study showed that the neuronal expression of MMP-9 was significant, particularly on mossy fibers and the granular cell layer of the dentate gyrus as well as temporal neocortex. In experimental models it has been noted that once activated MMP-9 can be inhibited by TIMP-1. Together MMPs and TIMPs control the pericellular environment, including the turnover of ECM proteins, bioavailability of growth factors and cytokines and shedding of membrane receptors (34). Moreover, TIMP-1 has an increased expression pattern following chemical SE and amygdala stimulation induced SE $(3,20,26)$. However, different from experimental studies, we found that TIMP-1 expression was weak in the hippocampus of the human MTLE-HS. The tissue material belongs to patients with medically refractory epilepsy that suggests that in the late stage of epilepsy TIMP- 1 expression is diminished. According to these findings it can hypothesize that increased MMP-9 expression can be a result of a disinhibition process. Still, it is important to bear in mind that epileptogenesis in experimental models can be different than human epileptogenesis.

This study also showed severe neuronal loss both in the CA subregions of the hippocampus and temporal neocortex. This apoptotic cell loss was very severe in the CA subregions. Moreover, the electron microscopic analysis of the hippocampus revealed severe mitochondrial and nuclear damage. Mitochondrial dysfunction and oxidative stress are known to be the acute consequences of injuries inciting acquired epilepsies. Besides, there are evidences supporting the role of mitochondrial oxidative stress not merely as a consequence of seizures, but an active contributor to seizures and epileptogenesis (40).

To our knowledge, our study is the first study showing that MMP-9 is associated with drug resistant MTLE -HS. However there are some limitations of our study. First of all, our data reflects only a small number of patients. Besides, the lack of comparisons with normal controls and other neurological diseases impeded us to make more clear suggestions. For all that because of the complexity to design tissue material based studies in human TLE, we think that our preliminary results will provide additional data in understanding the mechanism of epileptogenesis. Moreover, our results provide additional data about the mitochondrial dysfunction in human temporal lobe epilepsy. We hope that further studies will help understanding the mechanisms involved in seizureinduced cellular damage which is an essential basis for the development of rational neuroprotective strategies.

\section{ACKNOWLEDGMENTS}

The authors would like to thank Sibel Ozer for her excellent technical assistance. This study was partially supported by the Akdeniz University Research Foundation, Antalya, Turkey. 


\section{REFERENCES}

1. Acar G, Tanriover G, Demir R: Angiogenesis in neurological disorders: A review. Neurol Res 34:627-635, 2012

2. Aronica E, Zurolo E, lyer A, de Groot M, Anink J, Carbonell C, van Vliet EA, Baayen JC, Boison D, Gorter JA: Upregulation of adenosine kinase in astrocytes in experimental and human temporal lobe epilepsy. Epilepsia 52:1645-1655, 2011

3. Becker AJ, Chen J, Zien A, Sochivko D, Normann S, Schramm J, Elger CE, Wiestler OD, Blumcke I: Correlated stage- and subfield-associated hippocampal gene expression patterns in experimental and human temporal lobe epilepsy. Eur J Neurosci 18:2792-2802, 2003

4. Ben-Ari Y, Dudek FE: Primary and secondary mechanisms of epileptogenesis in the temporal lobe: There is a before and an after. Epilepsy Curr 10:118-125, 2010

5. Bozdagi O, Nagy V, Kwei KT, Huntley GW: In vivo roles for matrix metalloproteinase-9 in mature hippocampal synaptic physiology and plasticity. J Neurophysiol 98:334-334, 2007

6. Campbell SJ, Finlay M, Clements JM, Wells G, Miller KM, Perry $\mathrm{VH}$, Anthony DC: Reduction of excitotoxicity and associated leukocyte recruitment by a broad-spectrum matrix metalloproteinase inhibitor. J Neurochem 89:1378-1386, 2004

7. Chen JW, Naylor DE, Wasterlain CG: Advances in the pathophysiology of status epilepticus. Acta Neurol Scand Suppl 186:7-15, 2007

8. Dong X, Song YN, Liu WG, Guo XL: Mmp-9, a potential target for cerebral ischemic treatment. Curr Neuropharmacol 7: 269-275, 2009

9. Giorgi O, Orlandi M, Geic M, Corda MG: MK-801 prevents the decrease in 35S-TBPS binding in the rat cerebral cortex induced by pentylenetetrazol kindling. Brain Res Bull 27: 835-837, 1991

10. Gorter JA, Goncalves Pereira PM, van Vliet EA, Aronica E, Lopes da Silva FH, Lucassen PJ: Neuronal cell death in a rat model for mesial temporal lobe epilepsy is induced by the initial status epilepticus and not by later repeated spontaneous seizures. Epilepsia 44:647-658, 2003

11. Gorter JA, van Vliet EA, Aronica E, Lopes da Silva FH: Progression of spontaneous seizures after status epilepticus is associated with mossy fibre sprouting and extensive bilateral loss of hilar parvalbumin and somatostatin-immunoreactive neurons. Eur J Neurosci 13:657-669, 2001

12. Gorter JA, van Vliet EA, Rauwerda $H$, Breit $T$, Stad $R$, van Schaik L, Vreugdenhil E, Redeker S, Hendriksen E, Aronica E, Lopes da Silva FH, Wadman WJ: Dynamic changes of proteases and protease inhibitors revealed by microarray analysis in CA3 and entorhinal cortex during epileptogenesis in the rat. Epilepsia 48 Suppl 5:53-64, 2007

13. Gouder N, Scheurer L, Fritschy JM, Boison D: Overexpression of adenosine kinase in epileptic hippocampus contributes to epileptogenesis. J Neurosci 24:692-701, 2004

14. Heuser K, Hoddevik EH, Tauboll E, Gjerstad L, Indahl U, Kaczmarek L, Berg PR, Lien S, Nagelhus EA, Ottersen OP: Temporal lobe epilepsy and matrix metalloproteinase 9: A tempting relation but negative genetic association. Seizure $19: 335-338,2010$
15. Jankowsky JL, Patterson PH: The role of cytokines and growth factors in seizures and their sequelae. Prog Neurobiol 63: 125-149, 2001

16. Jourquin J, Tremblay E, Bernard A, Charton G, Chaillan FA, Marchetti E, Roman FS, Soloway PD, Dive V, Yiotakis A, Khrestchatisky M, Rivera S: Tissue inhibitor of metalloproteinases-1 (TIMP-1) modulates neuronal death, axonal plasticity, and learning and memory. Eur J Neurosci 22:2569-2578, 2005

17. Jourquin J, Tremblay E, Decanis N, Charton G, Hanessian S, Chollet AM, Le Diguardher T, Khrestchatisky M, Rivera S: Neuronal activity-dependent increase of net matrix metalloproteinase activity is associated with MMP-9 neurotoxicity after kainate. Eur J Neurosci 18:1507-1517, 2003

18. Kaczmarek L, Lapinska-Dzwonek J, Szymczak S: Matrix metalloproteinases in the adult brain physiology: A link between c-Fos, AP-1 and remodeling of neuronal connections? EMBO J 21:6643-6648, 2002

19. Konopacki FA, Rylski M, Wilczek E, Amborska R, Detka D, Kaczmarek L, Wilczynski GM: Synaptic localization of seizureinduced matrix metalloproteinase-9 mRNA. Neuroscience 150:31-39, 2007

20. Lukasiuk K, Kontula L, Pitkanen A: cDNA profiling of epileptogenesis in the rat brain. Eur J Neurosci 17:271-279, 2003

21. Meighan SE, Meighan PC, Choudhury $\mathrm{P}$, Davis CJ, Olson ML, Zornes PA, Wright JW, Harding JW: Effects of extracellular matrix-degrading proteases matrix metalloproteinases 3 and 9 on spatial learning and synaptic plasticity. J Neurochem 96:1227-1241, 2006

22. Michaluk P, Kaczmarek L: Matrix metalloproteinase-9 in glutamate-dependent adult brain function and dysfunction. Cell Death Differ 14:1255-1258, 2007

23. Mizoguchi $H$, Nakade J, Tachibana M, Ibi D, Someya E, Koike $H_{\text {, }}$ Kamei H, Nabeshima T, Itohara S, Takuma K, Sawada M, Sato J, Yamada K: Matrix metalloproteinase-9 contributes to kindled seizure development in pentylenetetrazole-treated mice by converting pro-BDNF to mature BDNF in the hippocampus. J Neurosci 31:12963-12971, 2011

24. Mizoguchi $\mathrm{H}$, Yamada K, Nabeshima T: Matrix metalloproteinases contribute to neuronal dysfunction in animal models of drug dependence, Alzheimer's disease, and epilepsy. Biochem Res Int 2011:681385, 2011

25. Nagy V, Bozdagi O, Matynia A, Balcerzyk M, Okulski $P$, Dzwonek J, Costa RM, Silva AJ, Kaczmarek L, Huntley GW: Matrix metalloproteinase- 9 is required for hippocampal late-phase long-term potentiation and memory. J Neurosci 26:1923-1934, 2006

26. Nedivi E, Hevroni D, Naot D, Israeli D, Citri Y: Numerous candidate plasticity-related genes revealed by differential cDNA cloning. Nature 363:718-722, 1993

27. O'Dell CM, Das A, Wallace Gt, Ray SK, Banik NL: Understanding the basic mechanisms underlying seizures in mesial temporal lobe epilepsy and possible therapeutic targets: A review. J Neurosci Res 90:913-924, 2012 
28. Okulski P, Jay TM, Jaworski J, Duniec K, Dzwonek J, Konopacki FA, Wilczynski GM, Sanchez-Capelo A, Mallet J, Kaczmarek L: TIMP-1 abolishes MMP-9-dependent long-lasting longterm potentiation in the prefrontal cortex. Biol Psychiatry 62: 359-362, 2007

29. Pitkanen A, Sutula TP: Is epilepsy a progressive disorder? Prospects for new therapeutic approaches in temporal-lobe epilepsy. Lancet Neurol 1:173-181,2002

30. Reeves TM, Prins ML, Zhu J, Povlishock JT, Phillips LL: Matrix metalloproteinase inhibition alters functional and structural correlates of deafferentation-induced sprouting in the dentate gyrus. J Neurosci 23:10182-10189, 2003

31. Rivera SK, Khrestchatisky M: Matrix metalloproteinases and tissue inhibitors of metalloproteinases in neuronal plasticity and pathology. Cambridge, Massachusetts: MIT Press, 1999

32. Rylski M, Amborska R, Zybura K, Michaluk P, Bielinska B, Konopacki FA, Wilczynski GM, Kaczmarek L: JunB is a repressor of MMP-9 transcription in depolarized rat brain neurons. Mol Cell Neurosci 40:98-110, 2009

33. Sharma AK, Reams RY, Jordan WH, Miller MA, Thacker HL, Snyder PW: Mesial temporal lobe epilepsy: Pathogenesis, induced rodent models and lesions. Toxicol Pathol 35: 984-999, 2007

34. Sternlicht MD, Werb Z: How matrix metalloproteinases regulate cell behavior. Annu Rev Cell Dev Biol 17:463-516, 2001

35. Suenaga N, Ichiyama T, Kubota $M$, Isumi $H$, Tohyama J, Furukawa S: Roles of matrix metalloproteinase- 9 and tissue inhibitors of metalloproteinases 1 in acute encephalopathy following prolonged febrile seizures. J Neurol Sci 266: 126-130, 2008
36. Szklarczyk A, Lapinska J, Rylski M, McKay RD, Kaczmarek $\mathrm{L}$ : Matrix metalloproteinase-9 undergoes expression and activation during dendritic remodeling in adult hippocampus. J Neurosci 22:920-930, 2002

37. Tanriover G, Demir N, Pestereli E, Demir R, Kayisli UA: PTENmediated Akt activation in human neocortex during prenatal development. Histochem Cell Biol 123:393-406, 2005

38. Tian $L$, Stefanidakis $M$, Ning $L$, Van Lint $P$, Nyman-Huttunen $\mathrm{H}$, Libert C, Itohara S, Mishina M, Rauvala H, Gahmberg CG: Activation of NMDA receptors promotes dendritic spine development through MMP-mediated ICAM-5 cleavage. J Cell Biol 178:687-700, 2007

39. Vezzani A, Granata T: Brain inflammation in epilepsy: Experimental and clinical evidence. Epilepsia 46:1724-1743, 2005

40. Waldbaum S, Patel M: Mitochondrial dysfunction and oxidative stress: A contributing link to acquired epilepsy? J Bioenerg Biomembr 42(6):449-455, 2012

41. Wilczynski GM, Konopacki FA, Wilczek E, Lasiecka Z, Gorlewicz A, Michaluk $P$, Wawrzyniak $M$, Malinowska $M$, Okulski $P$, Kolodziej LR, Konopka W, Duniec K, Mioduszewska B, Nikolaev E, Walczak A, Owczarek D, Gorecki DC, Zuschratter W, Ottersen OP, Kaczmarek L: Important role of matrix metalloproteinase 9 in epileptogenesis. J Cell Biol 180:1021-1035, 2008

42. Yang F, Wang JC, Han JL, Zhao G, Jiang W: Different effects of mild and severe seizures on hippocampal neurogenesis in adult rats. Hippocampus 18:460-468, 2008

43. Yong VW, Power C, Forsyth P, Edwards DR: Metalloproteinases in biology and pathology of the nervous system. Nat Rev Neurosci 2:502-511, 2001 